\title{
History of Islamic Political Movements in Turkey
}

\author{
Hakan Köni ${ }^{1}$, Nurhidayu Rosli ${ }^{1} \&$ Siti Aishah Mohamad Zin ${ }^{1}$ \\ ${ }^{1}$ Department of Public Administration of Namik Kemal University, Tekirdağ, Turkey \\ Correspondence: Nurhidayu Rosli, Department of West Asian Studies, National University of Malaysia, 43600 \\ Bangi, Selangor, Malaysia. Tel: 60-19-552-7646. E-mail: nurhidayur@gmail.com
}

Received: December 25, 2014 Accepted: January 8, 2015 Online Published: April 20, 2015

doi:10.5539/ass.v11n10p339

URL: http://dx.doi.org/10.5539/ass.v11n10p339

\begin{abstract}
This article investigates the history of Islamic political movements in Turkey. The time period of the article cover the time after the establishment of the Republic of Turkey in 1923 to the year 2000. It is argued in the article that Islamic movements were largely suppressed in the period between 1923-1945 when the country was ruled with a single party regime led by the Republican Peoples Party. With the introduction of multi-party political system in 1945, political Islam found the opportunity for political activism in the body of Democrat Party. But the political Islam found a more organized opportunity with the establishment of National Order Party in 1970 and National Salvation Party in 1971 by Necmettin Erbakan. Based on a programme of National View, the Turkish political Islam was known for its aim to support material development with a parallel moral and spiritual development with a reaction to the west in interstate relations. Turkish political Islam expressed itself with Welfare Party in 1983 to function until 1998 with some clear changes in its programme particularly in its agreement with contemporary political institutions and later support for Turkey's integration with the west. Turkish political Islam experienced its first great electoral success during the WP period. However, the WP is closed down in 1998 by the Constitutional Court due to allegations about anti-secularism and driven to a process of breakdown.
\end{abstract}

Keywords: Islamic political movements, political Islam, secularism, Turkey

\section{Introduction}

Republic of Turkey is geographically located at a juncture of Europe and Asia with its smaller part in Southeastern Europe and its larger part in Western Asia. The country has a very strategic location as it is stated by Rouleau (2000) in his Turkey's dream of democracy:

“.... and Turkey was too important a player on the international chessboard to be ignored. Bordering the oil fields of the Middle East, at the edge of the ex-soviet Turkic republics of the Caucasus and Central Asia (some of which are also rich in oil), and linked through its Ottoman past to the Balkans, Turkey has huge potential to play a stabilizing country in a turbulent region. Moreover, in the economic domain, Turkey had intensified its lucrative commercial and financial ties with Europe and had come to be considered one of the world's ten most promising emerging markets by the U.S government" (Rouleau, 2000).

The political trajectory of Turkey has been a subject of keen interest for the westerners for its geopolitical significance since the establishment of republic in 1923. $99 \%$ of the Turkish people are Muslim and Islam plays a significant role in the epistemology and the culture of the people. Majority of the Turks belong to the hanafi sect and together with sufism they apply a strong influence on the character and identity of Turkish people (Dzakirin, 2010).

After the collapse of the Ottoman Empire, although Islam is an integral part of the epistemology and culture of Turkish society, political parties and organizations are prevented from having religious references in the name of securitizing secularism. However, the Islamist group found religious expression via contemporary political norms and institutions under the banner of conservative parties. Conservative parties came to the government multiple times with their policies towards freedom of religion, belief and conscience. In this article, the last six decades of Islamic political movements will be taken under analysis with a look into how they cohabitated with democratic political life. The main argument of the article is that political Islam in Turkey has met with favorable and unfavorable conditions in this period to become the major political actors some times and to be prohibited from political activism some others. 


\section{Concept of Islamic Political Movement}

A movement could be identified as a group of individuals who share the same objectives, efforts and resolution to achieve some particular goals. As a particular kind of movement, an Islamic movement could be distinguished from others with the following characteristics that it embodies: 1) formation by a group of Muslims; 2) use of Islam as a platform in constructing goals and method; 3) support the implimentation of Shari'a Law; 4) the pursuit of commended principles set by the ulama (Anonymous, 2004). Abdurrahman (2009) classifies Islamic movements in three categories as follows:

1) Isolationist Islamic movements: These kind of movements include tariqats and sufi groups. The major purpose of these groups is salvation in the hereafter. They tend to be more spiritual with a distaste of mundane activities. Isolation (uzlah) from the society is a common practice for members of these movements.

2) Activist Islamic movements: These kind of movements view the society as a group of individuals who have to be in dialogue and interaction with one another. The individual develops his faith and morality via contact with others through learning and socialisation. This is considered as a key for a healthy society to the members of these movements.

According to Hafidz (2004), in order to fulfill its major goal, every Islamic movements must go through two stages, i.e., (1) establishment and recruitment, and (2) survival and enlargement. A successful Islamic movement is supposed to have a well-established foundation with its major functions and principles clearly defined. People must be invited to the movement upon this clearity and they have to know their rights and obligations very well. In the second stage, the movement must declares itself to the society and face its opponents in a proper way by dealing with them according to the norms and methods commended by each religious schools of thought. In contemporary world states where the Muslims constitute a large majority, the Islamic movements often meet with repression on grounds of secularism, socialism, nationalism etc. at all stages of their existence.

In our case here in this article, the Islamic movements are found to be pressurized by a kind of extreme secularist state formation which prohibited the use of religion in any party movement and propaganda as well as any other thing related with religion. The defense of sharia regime, transition to an Islamic state, pursuit of Islamic principles in economic and political life, etc. have all been absent in legal Islamic movements in Turkey in order to voice ideas on morality and virtue (Landau, 1974).

\section{Islamic Political Movements in Turkey from 1920s to 1950s}

The role of Islam in socio-political life in Turkey changed substantially with the collapse of the Ottoman Empire and the establishment of the Republic of Turkey in 1923. The change in the Turkish geography was not a change in the name of the state only. With the specific type of modernisation adopted by the founders of the Turkish Republic, particularly Atatürk and his close associates, the place of religion in Turkish socio-political and economic life is minimized substantially. Atatürk and his close associates shared the idea that the Ottoman Empire was weakened because of the involvement of religious institution in political affairs. Furthermore, the rejection of policies of modernization by the ulama class and their pressures on the bureaucrats with this regard had left the state in a state of backwardness. The country was unable to compete with the contemporary states and wars were almost all ended in defeats with massive territorial losses. It was a major concern of the founders of the Republic to minimize the role of religion in political life and a thick list of reforms were adopted for this purpose.

If we are to summarize the reforms in this regard: In March 1923, the caliphate is abolished. The constitutional article denoting Islam as the religion of the state is removed in 1928. The principle of secularism is added to the constitution in 1937. The Islamic Civil Code is changed with the Swiss Civil Code in 1926. Religious foundations, associations, schools, sufi tariqats are all banned in 1924. Educational and legal system is totally secularized. In 1928, the alphabet is changed from Arabic to Latin. In 1931, Islamic measurement system is changed with the metric system. Weekly holidays are changed from Friday to Sunday, surname law is introduced and use of religious attire is banned in the public (Mardin, 1962).

From 1923 to 1945, there was only a single party established by Atatürk, i.e., Republican Peoples Party (RPP). Between this period, Islamic movements withdrew into isolation to cut their links with politics. An active member of the independence movement, Said Nursi who is the founder of the Nurcu movement in Turkey also had to terminate his political career. It was in this period that he wrote a majority of the collection of books known as Risale-I Nur (Note 1). The teachings spread throughout the Turkish society to preserve the understanding and practice of Islam. The history of the Nurcu Movement is mentioned in Ali (2001), Islam dan Sekularisme as follows: 
"Said Nursi's involvement in politic has started since he was in Mardin. During this time, he had merged into the Young Turk movement to free Turkey. He called them to establish Muslim unification in order to save the weakening Ottoman Empire. However, when he realized the tendency of Kemal to implement secular policies which conflicted with Islamic teaching, Said Nursi decided to leave politics and focus on writing and educating the society with Islamic faith..." (Ali, 2001)

Although it was banned to open operation centers and mosques, the Naqshibandi movement survived underground with its limited educational, judicial and ritual activities particularly in regions occupied by the Kurds. They were thus saved from political impositions and indoctrinations via political and educational reform campaigns of the statesmen (Yavuz, 2003). Both the Nurcus and Naqshibandis represented a conservative Islamic political movement in this period who preserved their Islamic identity and lifestyle. The members of these movements would take part in the formation of Islamic political movements in the future and they would show utmost effort to regenerate Islamic values in the society. Necmettin Erbakan, Recep Tayyip Erdoğan, Turgut Özal, Ahmet Davutoğlu as the Presidents and Prime Ministers of the country all had direct links with one or two of these movements.

\section{Islamic Movements in Turkey during the Multiparty Political Era $(1945 \rightarrow)$}

Although Atatürk paid great efforts to secularize the country, the society was still highly conservative. When the country is transitioned to democracy in 1945 with the permission of opening new parties, the conservatives united in the Democrat Party (DP) were unable to take to the government yet. There were still fears from the secularist and the elections were not held in a democratic way. The DP led by Adnan Menderes was not given many chances to campaign for the elections and the elections were held according to the principle of open voting and secret counting of the votes. Therefore, the RPP held the government until 1950. In the parliamentary elections of 1950, the DP unexpectedly received a majority of the votes and placed in the government for two successive terms until 1960. The DP had members from the conservatives and liberals at the same time for it was open to all people feeling isolated by the Kemalist elites. So, the party adopted various conservative and liberal policies at the same time. Among its conservative policies were i) prayer calls return from Turkish to Arabic; ii) remove the ban on going for Hajj; iii) reopen the Imam and Hatip Schools; iv) form teaching courses on religion and morality in the schools; v) broadcast Qur'an recitation in the radio and the TV.

However, it is argued that the DP isolated the conservatives by time (Geyikdağı, 1984). DP deputies rejected to be an Islamic political movement. It was more like a liberal party with electoral concerns thus introducing the maximum amount of reforms for the electorate. That is understood better when we look at the preference of the party to apply free market economic norms in the economy. The party was also divided with the Nurcu movement by time for it was insistent on judging Said Nursi with claims that he had a secret agenda to change the regime in Turkey. Said Nursi was kept under arrest for almost all through DP ruling period. The introduction of insult law against Atatürk as the punishment of those people insulting Atatürk also corresponds to DP's reign in the government.

Making use of the opportunity to get into politics in 1945 in a chaotic way, the conservatives would show their more coherent activism after 1960s. It was understood by the conservative members of the DP that they were unable to promote conservative ideals in parties like DP and that they had to establish their own party. The rupture of the DP between conservative and liberal policies was inevitable.

\section{Erbakan and National View Period in Turkey}

\subsection{National Order Party (Milli Nizam Partisi)}

According to Yavuz (2003), Nurcus and sufi sects have been very influential in the emergence of Turkish conservatism as a political movement. Increasing social activism of such religious organisations under the climate of extensive rights and freedoms recognized after 1950s eventually led to the appearance of some political voices in favor of the establishment of a clearly defined conservative party. The Islamists found an opportune political environment and they aptly used it under the leadership of Necmettin Erbakan to establish the National Order Party (NOP) in January 1970. The NOP campaigned with the programme that the development in material aspects of life must never go without any respect for belief and morality. Turkey owned a thousand years old Islamic heritage and that could not have been neglected with oppressive and negligent governmental policies. Spiritual and moral development was also necessary for a healthy material development meeting the psychological needs of the people at a time of rapid industrial and social change. The NOP was thus critical with the negligent secularist policies of the state. The programme of the NOP found support primarily by the conservative members of Süleyman Demirel's Justice Party (AP) to stretch its appeal towards small merchants, town and village people (Redzuan \& Mashitah, 2005). 
Toprak (1981) identifies NOP as a reactionary party with its clear opposition towards a number of things including i) Turkey's dependence on foreign aids and capital; ii) low level of economic development and income disparity; iii) westernization in social and cultural terms; iv) communism and such radical leftist ideologies. To state it more clearly, the NOP defended economic independence, economic development, moral and spiritual development as recipe for a prosperous country. The NOP did not defend Islamic sharia regime. It was secular, but its secularism differed from those of the state establishment. For NOP, secularism was emancipatory rather than oppressive. It guaranteed freedom of belief and conscience. It meant that neither the state nor any other entity was allowed to intervene in the world of conscience of the people (Geyikdagi, 1984).

Though the NOP paid special attention to avoid any campaign on Islamic law and statehood (Redzuan, 2005), it was thought to be the other way by the state establishment. As a result, the party was closed after the military memorandum of 1971 with a number of other parties. The reason for party closure was indicated as due to its attempt to undermine the principle of secularism and establish an Islamic state. After the party was closed, its leader Erbakan fleed to Switzerland to avoid prosecution (Binder, 1988).

\subsection{National Salvation Party (NSP)}

After the closure of the NOP, one of the generals, General Refet requested from some of Erbakan's friends to establish a new party. The General had the concern to cut the appeal of the mainstream rightist Justice Party. The event thus led to the formation of a new party on 11th October 1972 using the name National Salvation Party (Milli Selamet Partisi) (Yavuz, 2003). The party was again led by Necmettin Erbakan. This time, there was still high support for the party from the people. The NSP campaigned from over 42 provincial centres and 300 lower level centres for higher accessibility to the people. The membership of the central party organisation included people with elite and professional background with the omission of the lower segments of the society mostly. But it has founded substantial support from the peripheries of the society from the small merchants, bazaar society, villagers and towns people. The party's reactionary vision attracted support from many who were uncomfortable with materialist and positivist state structure (Toprak, 1981). A common characteristic of all NSP members and supporters was their involvement in religious and moral activities as part of their family background, education or their membership to some religious organisations.

NSP was known for its Milli Görüş idea (National View). National View could be considered as the party's ideology or programme of the NSP. The aim was to bring the society back to its original spiritual and moral roots. The way to do it was through democratic choices of the people and the freedom of belief and conscience stated in the constitution. Erbakan often opposed state intervention in the religious belief and practices of the people and considered it as a violation of basic human right. According to Erbakan, Turkish constitution had to be amended substantially in order for it to be a contemporary constitution. The people were banned from religious life and practices to protect the principals of secularism. The Article 19 of the constitution prohibiting the use of religious terminology by the politicians on grounds of preventing religious exploitation had to be abolished.

In foreign policy, according to National View, Turkey had to give up the efforts to enter the European Economic Community (EEC) because it was believed that the EEC was a Christian club aiming to undermine the Muslim world. It was impossible for Turkey to compete with developed European economies as well to inhibit the growth of the Turkish economy and to make it dependent on foreign economic intervention. Turkey was supposed to unite with the Muslim world for economic, political and military partnership for a more promising and realistic development project (Geyikdagi, 1984).

Erbakan's reactionary rethoric worked well with a substantial support in the elections taken from the people. In 1973 general election, the party received $11.8 \%$ of the votes. And in 1977 general election, it received $8.6 \%$ of the votes. This way the NSP had been the third party in the assembly after the RPP and the AP. According to a research by Toprak (1981), the majority of the NSP voters with religious concern had voted for the party. The NSP incorporated a heavy industrialisation scheme into its programme as mechanism for national development. The two major policy concerns of the party were thus industrial and moral development (Yavuz, 2003).

The NSP tended to be pragmatist in its election campaigns. The elitist and urban character of the electoral appeal of other parties were well-noted by the NSP. The rural people who constituted the majority of the citizen were mostly from party activism and the policies were addressed to the concerns of the urban people. The NSP thus displayed itself as the party of the peasants and rural people. Furthermore, the majority of the countrymen in Turkey tended to be conservative generally. The programme of the party in its own was symphathetic for the people with its conservative ideals. The rigid secularism of the state elites was not acceptable by the countrymen who wanted to preserve their religious beliefs and practices regardless how the country changed. The NSP was thus promised them social, political and public activism without abandoning their conservative lifestyle (Toprak, 
1981; Frey, 1966).

NSP's commitment to conservative political ideals was tested when they had been a coalition partner in the government with RPP on 24 January 1974. As a party with Islamic ideology, Yavuz (2003) wrote about MSP's image in coalition government as follows:

"The image of the MSP in the coalition government was that of a party dedicated to the promotion of Muslim morality, Ottoman heritage, freedom of conscience, the modernizing of Turkey's economy through rapid industrialization, and concern for the 'little man'. This image in turn, helped the MSP to restore calls for Islamic values as a potent force in Turkish politics and society. The party considered the family to be crucial for molding the moral and spiritual character of the country's youth. It also stressed social and economic justice and the equitable distribution of national wealth (Yavuz, 2003)."

It was a natural state for the Muslims to follow their religious values. Thus democracy in a country where Muslims are in the majority would be influenced by Islam. Again Yavuz (2003) identified the major policy concerns of the NSP as follows:

"Criticisms of long hair, miniskirts, pornography, TV, movie and theatre programmes influenced by Western culture, wearing of shorts by female students during gym classes, tourist accomodations, the youth's lack of respect for parents and older people, imitating Western culture, lack of religious belief among the youth, the dissapearance of traditional family life, and the mushrooming of nightclubs (Yavuz, 2003)."

However, the NSP's coalition with the RPP did not last long. The economic condition of the country was deteriorating. The politicians were voicing their support for radical ideologies. The streets had turned to hotbeds of terrorism and each political party was defending its own radical's ideology. An average of 25 people was dying in the streets from terrorist attacks every day. The coalition government thus fell on 31st December 1977. Attempts by the leading party leaders to establish a new government ended in failure due to ideological concerns and disagreements on the distribution of ministries. Eventually Suleyman Demirel managed to establish a government after months being a minority government. However, due to its minority status in the parliament, the government was uneffective. In the meantime, inflation was not taken under control, the streets were still ravaged by anarchists and terrorists, and under those circumstances, the army decided to take the political control in its hand with a military intervention.

The 1970s were very unstable and chaotic in Turkish political life. Governments did not survive long. Inflation had risen up as high as $140 \%$. Political violence was at peak with 2500 individuals being killed between 1978 until 1979. And during the period after 12th September 1980, 2000 people were killed including students, workers, politicians, teachers, professors, journalists, labour union members, bank managers and police officers (Singer, 1981). This situation had caused the millitary to intervene and seize the government.

\subsection{Welfare Party (WP)}

The period after the military intervention in 1980 brought some changes regarding conservative people's approach to the political phenomena. The conservatives were now more in favor of living in a democratic society. The Welfare Party established in 1983 thus had its differences from the NSP line in a number of certain key areas. The WP would be more globalist, liberal in economy and more aware of the realities of international political system. This was so because the economic situation of the people was getting better and channels of communication were getting more powerful with the west. Peace, prosperity and stability was to be a major concern for the people.

\subsubsection{Party's Background}

The WP is established on 19 July 1983 with majority of its members being imported from NSP. The WP was very ambitious with its goals to re-shape the socio-political and economic face of the country with democratic political means. The educational system would be changed from its atheist-materialist formation to a system more compatible with belief and conscience. The type of liberties damaging public morality would be minimized. The national economic system based on interest and monetarism would be changed into an interest-free and standard system.

Due to his ban from politics, Erbakan was not one of the founders of the WP, but he quickly joined the party after the abolition of the ban in 1987. However, the WP was not allowed to compete in the election in 1983 because of political limitations. But the party joined the municipal elections in 1984 and won the municipalities in Van and Urfa provinces. According to Yavuz, the WP tended to be a pragmatist party in terms of its inclination to address to the sentiments and interests of the people. Religion had a strong sentimental power among Turkish people and the party was making best use of it in its public appearances by promising to introduce rights and 
liberties for the religious people. As part of this tendency, the WP had declared its support for a Just System (Adil Düzen). The Just System was introduced as the major programme of the party by which the inequalities among the citizens would be eliminated, the national income would be distributed more equally, the oppression-like interest, excessive taxation, monetarism, etc. would be minimized, everyone would have their jobs and the people would live their beliefs and ideas freely.

\subsubsection{The WP in Politics}

With the active involvement of the WP in politics, and its experience in politics, practicality turned as a major concern for the party. The previous scepticism about free market and small state were dismissed. The party was meeting with the demands and interests of the grassroots involved in civil society organisations, investment and production. The closure of the previous parties by the Islamic movement in retrospect was another concern to drive the WP deputies to be more careful with their conservative programme. However, the WP did not abandon the goal to islamize the society and politics with legitimate means. The WP had turned to a massive political, social, cultural, economic, educational and civil society organisation with bottom-up and top-down practices to materialize its major goals (Vali, 2001).

The WP organisation was working very actively to broaden its support base. Civilian and political members of the party were visiting the people almost house by house. The people were invited to support the WP in public, educational, economic, social and all other types of events and entities. The popularity of the WP was growing substantially. The allegation of corruption scandals involving other parties like True Path Party (TPP), Motherland Party (MP) and RPP was adding further chances for the WP in driving the people to support a clean party. The support from MUSIAD (Association of Independent Industrialists and Businessmen) as a major union of employers earned the party a powerful ally in the sphere of the economy on the other side. The increasing support of the sufi sects, other religious communities, people in rural Turkey meant that the party was not alone with its voters anymore. As a result, the WP made a substantial rise in its electoral share in the elections. In municipal elections of 1994, the WP won $19.10 \%$ of the votes. And one year later in general elections of 1995 , the WP won $21.37 \%$ of the votes to be the winning party of the elections. Yavuz (2005) interprets the victory of the WP in the elections as follows:

"Both elections ended with the victory of the pro-Islamic WP. The results of the elections revealed a society sharply divided along secular versus Islamists sociocultural lines. In this context, the RP is one of the main avenues for political Islam to articulate its demands within the public sphere. It represents a platform for those who seek to change the secular system as well as for those who demand reforms in the system, that is, within bureaucratic state structure. This competing, even conflicting, campaign to reorganize the political center and transform the bureaucratic system has mobilized large segments of the population that range from Kurdish groups to the new merging Anatolian bourgeoise, all in the name of identity and justice"(Yavuz, 2005).

Related with those explained above, the success of the WP could be associated with the following factors: i) Erbakan's leadership; ii) interpersonal belief existed among the society through mobilization strategies; iii) the role of WP's representatives in social events like wedding and mourning events; iv) good relations with other organizations such as the National Youth Foundation; v) structured relations with Turkish labours in Europe and some Islamic movements in other Islamic countries like The European National Outlook Organization (AMGT) and International Humanitarian Help (IHH); vi) conducting regular meetings at the coffee shops or personal houses every night and; vii) well-management of all rising issue.

\section{28 February 1997 Process}

The WP won the elections in 1995, but it did not hold the majority of the seats in the parliament. It had to form a coalition with the TPP. Being a major coalition partner for the first time, the WP was tested for the type of policies that it would try to implement particularly regarding conservative ideals. Contrary to what it has argued in its previous campaigns, the WP did not attempt to distance Turkey from the west by turning its back to the EU, UN and NATO. Relations with Israel were not cut, but rather in a trend of waiting for further development. The idea of removing the interest and changing the banking system was never brought to the agenda. However, there were calls from the grassroots for an Islamic revolution to which the party leadership had sometimes acceded. Party deputies were sometimes observed to express their longing for Islamic law, statehood and even jihad for the purpose.

The WP thus turned out to attract the secularists' attention including the army, the judiciary and the media. The secularist media set out for regular attacks by documenting the talks and campaigns of the WP on TVs and newspapers. The WP was drawing attention by introducing controversial policies and activities like abolishing the ban on headscarf for students, organizing iftar dinners in the official prime minister's residence, trying to 
construct mosques on popular public places, trying to transition the legal system to a multiple system of law (Erol, 2000). Erbakan's attempts to improve relations with Iran, Libya and Egypt on religious bases were to be another source of attention (Akpinar, 2001).

The WP was thus subjected to an intensive wave of criticism and suppressions by the secularists with armed, legal and civil society actions taken up all together (Jenkins, 2001). The enchantment of slogans for the introduction of sharia during a night organised by the mayor of Sinjan District in Ankara in February 1997 instigated the military to take armed action by driving the tanks to the area. During the National Security Council Meeting held in its aftermath, the army presented the government a list of actions to be taken against religious radicalism. Though Erbakan agreed to take the actions, the events deteriorated and Erbakan had to resign from the Government particularly with the additional reaction of the coalition partner to the party (Köni, 2013; Rouleau, 2000).

\section{Post-28 February (Post-Islamism) Process}

The term post-Islamism is developed by a number of prominent observers in Europe to refer primarily to a shift in the attitudes and strategies of Islamist militants in the Muslim world. Asef Bayat (1996) explains post-Islamism as follows:

"In my understanding, post-Islamism represents both a condition and a project which may be embodied in a master (or multi-dimensional) movement. In the first instance, it refers to a political and social condition where, following a phase of experimentation, the appeal, energy, and sources of legitimacy of Islamism get exhausted even among its once-ardent supporters. Islamists become aware of their system's anomalies and inadequacies as they attempt to normalize and instutionalize their rule. The continuous trial and error makes the system susceptible to questions and criticisms. Islamism becomes compelled, both by its own internal contradictions and by societal pressure, to reinvent itself, but does so at the cost of a qualitative shift. The tremendous transformation in religious and political discourse in Iran during the 1990s exemplifies this tendency. Not only a condition, post-Islamism is also a project, a conscious attempt to conceptualize and strategize the rationale and modalities of transcending Islamism in social, political, and intellectual domains...it represents an endeavour to fuse religiosity and rights, faith and freedom, Islam and liberty" (Asef Bayat, 1996).

There has been a critical view on post-Islamism. Some scholars view it as premature generalization about the end of Islamism (understood chiefly in terms of the establishment of an Islamic state). Scholars like Gilles Kepel view post-Islamism as the departure of Islamists from jihadi and Salafi doctrines, while for others like Olivier Roy perceived in terms of the 'privatization' of Islamization (as opposed to Islamization of the state), where emphasis is placed on changes in how and where Islamization is carried out, rather than its content.

As the case so far in Turkey, Justice and Development Party (JDP) is using post-Islamism approach in dealing with the pressure from the secularist group and military intervention in politics. It stresses more on individual choice and freedom, with democracy and modernity.

\section{Diverging Road: Felicity Party (FP) and Justice and Development Party (JDP)}

After the dissolution of WP under pressures by the secularists in 1997, the members of the party went on with the establishment of a new party, the Virtue Party (VP). The VP was needed as an institutional anchor to replace WP in parliament (Dzakirin, 2010). However, the party was torn apart due to split on various issues. A group of party members called as traditionalists continued to defend the old ways in the party while another one called as innovationists declared that the movement needs to change a lot to genuinely incorporate democracy, human rights, rule of law, free market economic system, multilateralism into its programme (Köni, 2014). The split eventually materialized with the division of the movement into two and when the VP is closed by the Constitutional Court, the innovationists established the Justice and Development Party (Dzakirin, 2010). Meanwhile, the traditionalists established what now called Felicity Party.

\section{Conclusion}

The chronology of Islamic political movements above shows the evolution of Islamic political movements approach to power in a secular system. From author's point of view, the evolvement was due to obstacle from the establishment especially the military. As a result, the military-civilian relation has reached a deadlock stage due to regular political intervention by the military in a civilian government. Thus, the Islamists are in constant search for the right approach to strengthen the civilian power over the military and avoid creating severe conflict in the political lanscape. Though the approach of each political movement seems to be changing, the Islamists goal remain the same that is to islamize Turkey and preserving the religious affairs of Muslim in Turkey.

To summarize the history of Islamic political movements in Turkey during the Republican history, we should 
start by saying that they were legally forbidden until 1950s during which the government was controlled by the highly secularist RPP known for its reaction to public expression of Islamic practices. However, with the introduction of multi-party political system in 1945, there started to appear conservative voices in Turkish political system. The conservatives organised in the liberally oriented Democrat Party until 1960. From then to 1970, they displayed activism in Justice Party. And in 1970, with Necmettin Erbakan's leadership, the conservatives united in National Order Party. Being closed in 1971, the NOP is followed by the National Salvation Party. Known for its campaign for National View programme, Erbakan-led conservative political parties defended the necessity of moral and spiritual development by the side of material development. The National View rejected integration to the west in political and social terms and supported Turkey's integration with the Muslim world.

The NSP is closed in 1980 and it is followed by the formation of the WP in 1983. Experiencing significant changes since then, the WP appeared with a programme not in opposition to integration with the west nor in support of Islamizing the economy. However, it was spotted to support the idea of Islamic law and statehood in various cases because of which it was closed in 1998 by the Constitutional Court. After a number of chaotic years, political Islam in Turkey found its expression in the establishment of the Justice and Development Party to be the most powerful and stable party of Turkish democratic history holding the government in its hand since it is established.

\section{Acknowledgements}

Special thanks to Dr. Hakan Köni for his guidance during the research and writing process of this article. The completion of the article is largely facilitated with our research sponsored by the Department of Public Administration of Namik Kemal University during the summer of 2014.

\section{References}

Abdurrahman, H. (2004). Diskursus Islam: Politik dan spiritual. Penerbit Al-Azhar Press.

Akpınar, H. (2001). Post-modern darbenin öyküsü (28 February-of a post-modern coup), in Turkish. Ankara: Ümit Yayıncilik.

Ali, H. A. M. (2001). Islam dan Sekularisme.

Anonymous. (2004). Materi dasar Islam. BKIM IPB Press.

Bayat, A. (1996). The coming of a post-Islamist society. Critique: Critical Middle East Studies, (9), 43-52. http://dx.doi.org/10.1080/10669929608720091

Binder, L. (1988). Islamic liberalism: A critique of development ideologies. Chicago: University of Chicago Press.

Burak, B. (2011). The role of the military in Turkish politics: to guard whom and from what? European Journal of Economic and Political Studies, Ejeps, 4(1), 143-170.

Dzakirin, A. (2010). Kebangkitan gerakan Islam: Analisis strategi dan polisi AKP Turki memenangi pilihan raya umum. Kuala Lumpur: Alam Raya Enterprise Sdn. Bhd.

Erol, Ö. (2000, November 7). Radikal.

Frey, F. W. (1966). Regional variations in rural Turkey. Report No.4. Center for International Studies. MIT. Cambridge: Mass.

Geyikdağı, M. Y. (1984). Political Parties in Turkey. New York: Praeger Publishers.

Jenkins, G. (2001). Context and Circumstances: The Turkish military and Politics (Adelphi Paper 337). London: International Institute for Strategic Studies.

Khalid, A. M. (2003). Soal-jawab seputar gerakan Islam. Penerbit Al-Islam Press.

Köni, H. (2013, April). Regime opposition as a source of party policy change: The case of the Turkish religious right. International Journal of Business and Social Science, 4(4), 215-224.

Köni, H. (2014, May). Globalisation as an agent of party change: The case of the Turkish religious right. Al-Sabah Working Paper Series 11 (pp. 1-20). Durham: Durham University SGIA.

Landau, J. M. (1974). Radical politics in modern Turkey. Leiden: E.J. Brill.

Mardin, S. (1962). The genesis of young Ottoman thought. Princeton University Press.

Mardin, S. (1971). Ideology and religion in the Turkish revolution. International Journal of Middle East Studies, 
2, 197-211. http://dx.doi.org/10.1017/S0020743800001094

Mardin, S. (1977). Religion in modern Turkey. International Social Science Journal, 29, 282-283.

Mardin, S., \& Toprak, B. (1981). Islam and political development in Turkey. Leiden: Brill.

Othman, R., \& Mashitah. (2005). Islam dan politik di Turki. Selangor: Tradisi Ilmu Sdn.Bhd.

Rouleau, E. (2000). Turkey's dream of democracy. Foreign Affairs, 79(6), 100-116. http://dx.doi.org/10.2307/2 0049970

Singer, M. (1981). Turkey in crisis. Current History, 80(462), 27-31 \& 39-40.

Toprak, B. (1984). Politicisation of Islam in a secular state: the National Salvation Party in Turkey. In S. A. Arjomand (Ed.), From nationalism to revolutionary Islam. Albany: State University of New York Press.

Vali, N. (2001). The Islamic leviathan: Islam and the making of state power. New York: Oxford University Press.

Yavuz, M. H. (2003). Islamic political identity in Turkey. New York: Oxford University Press.

\section{Note}

Note 1. The Risale-i Nur collection is often identified as a contemporary interpretation of Qur'an. Said Nursi successfully attempted to bring solution to the questions arising about belief with his use of modern sciences and narrative. Parts of the books include explanations of the verses in Qur'an, but they are mostly used to bring explanation to various questions and issues raised.

\section{Copyrights}

Copyright for this article is retained by the author(s), with first publication rights granted to the journal.

This is an open-access article distributed under the terms and conditions of the Creative Commons Attribution license (http://creativecommons.org/licenses/by/3.0/). 